\section{New ruling on unlawful detention}

Sir: Until recently, people with mental incapacity who have expressed neither consent nor dissent to their detention as informal in-patients, have not been subject to the safeguards incorporated within the 1983 Mental Health Act. This practice was brought under closer scrutiny last year, resulting in a major revision of issues surrounding the care of people suffering from learning disabilities. The case in question ( $\mathrm{L} v$. Bournewood Community and Mental Health NHS Trust) (Inability to consent makes detention illegal, The Times, 8 December 1997) was taken to the Court of Appeal by the 'next friend' of a man with autism who had been informally admitted to Bournewood Hospital. The appellant could express neither consent nor dissent to the admission. The initial request for a judicial review had initially been refused on the grounds that the appellant was "free to leave" (Pamment, 1997). However, this decision was overturned by the Court of Appeal, who ruled that the appellant had been unlawfully detained.

The main point arising from this ruling is that a patient who is incapable of giving informed consent to admission cannot be admitted informally to hospital even if they do not dissent. Second, if a patient lacks capacity and no application for admission under the 1983 Mental Health Act is made, hospitals are entitled to look after the patient to prevent him/her from harming themselves until reasonable satisfactory arrangements can be made for their care.
The new ruling also has wide-ranging implications for the care of people with dementia. In the case of new patients to a mental health service admission under Section 2 of the Mental Health Act may be appropriate. In the case of patients with an established diagnosis of dementia admitted for respite care, the issue of consent and unlawful detention becomes a legal quagmire. The implications from the new ruling are already being addressed (Court of Appeal Judgment: $L v$ Bournewood Community and Mental Health Trust. Department of Health, 19 December 1997), but the sheer heterogeneity of clinical situations to which it applies will undoubtedly have financial sequelae in already over-stretched trust budgets.

PAMment, D. (1997) Trust's fight to stay on the right side of the law over detention. Health Service Journal, 13 November.

R. RAO, 3 Keightley Drive, New Eltham, London SE9 $2 H F$

\section{Secretary's blunder}

Sir: We have received a report from a consultant psychiatrist, Mr C. Psych, to the effect that the matter should be delayed as the defendant is receiving treatment and counselling.

(Letter from Borough Secretary of a town in the south of England).

I. G. BRONKS, 10 Harley Street, London WIN IAA 